\title{
STRATEGIC MANAGEMENT IN INCREASING EDUCATIONAL PARTICIPATION FOR 12-YEARS COMPULSORY EDUCATION
}

\author{
Dadan F. Ramdhan \\ Universitas Islam Negeri (UIN) Sunan Gunung Djati Bandung \\ Jl. A.H Nasution No.105 Cibiru Bandung, Jawa Barat, Indonesia, 40614 \\ Email: dadanramdhan74@uinsgd.ac.id

\section{Isop Syafe'i} \\ Universitas Islam Negeri (UIN) Sunan Gunung Djati Bandung \\ Jl. A.H Nasution No.105 Cibiru Bandung, Jawa Barat, Indonesia, 40614 \\ Email: Isop.syafei@uinsgd.ac.id
}

Received: 07, 2019. Accepted: 12, 2019. Published: 12, 2019.

\begin{abstract}
In Indonesia, education has many problems to take into consideration. One of them is that SMP (Sekolah Menengah Pertama/Junior high school) graduates could not continue to SMA (Sekolah Menengah Atas/Senior high school) level. This research was aimed at investigating accurate data and information regarding strategic management administered by education and culture office of Sukabumi city in improving educational participation. This research applies strategic management model proposed by Hunger-Wheelen. This study was qualitative using case study. Data were collected using interview, documentation, and observation. The education and culture office of Sukabumi City had no specific vision and mission for the implementation of 12 -year secondary education. The strategies included providing financial support in many programs like kartu pintar/smart card, direct help card, and scholarships for poor families. The implementations were based on programs, budgets and procedures. In general, the implementation had been successful but it has two programs which had not succeeded namely retrieval program and program to support student who were prone to drop out. Strategy evaluation was done according to the system, types, and the management.
\end{abstract}

Keywords: Compulsory Education, Educational Participation, Strategic Management

\section{ABSTRAK}

Di Indonesia, Pendidikan memiliki banyak masalah. Salah satuny a adalah masalab terkait lulusan SMP yang tidak. bisa melanjutkan studi ke jenjang SMA. Penelitian ini bertujuan untuk. menginvestigasi data akurat dan informasi terkait managemen strategis untuk meningkatkan partisipasi Pendidikan siswa yang dilaksanakan oleh dinas Pendidikan dan kebudayaan kota Sukabumi. Penelitian ini mengaplikasikan manajemen starategis yang diajukan oleh Hunger-Wheelen. Penelitian ini menggunakan pendekatan qualitative dengan menggunakan studi kasus. Data dikumpulkan dengan menggunakan Teknik interview, dokumentasi dan observasi. Temuan menunjukan bahwa Dinas Pendidikan dan kebudayaan kota Sukabumi tidak memiliki visi danmisi yang jelas terkait implementasi Pendidikan 12 tahun. Strategi yang dilakukan adalab berupa bantuan keenangan dalam berbagai bentuk program seperti kartu pintar, bantuan langsung dan juga beasiswa untuk keluarga miskin. Implementasi dilaksanakan berbasis program, anggaran dan prosedur-prosedur. Secara umum, implementasi bias dikategorikan sukses namun ada beberapa bal yang perlu diperabtikan terkait dua program yang belum berjalan optimal yaitu retrieval program dan bantuan untuk murid yang terancam keluar sekolah. Strategi evaluasi dilaksanakan sesuai dengan system, tipe dan manajemen. Program ini bisa dibuktikan dengan melihat implementasinya selama kurun waktu 2008-2012 yang menunjukan adanya penambahan yang signifikan dalam hal angka partisipasi kasar dan murni untuk sekolah jenjang SMA.

Kata Kunci: Wajib Belajar, Partisipasi Pendidikan, Manajemen Startegis 


\section{INTRODUCTION}

Educational development policy has been formulated in line with the international conventions on education or related to principles of educational development such as: Education for All (EFA), the Convention on the Rights of the Child, the Millennium Development Goals (MDGs), and the World Summit on Sustainable Development. In Indonesia context, there are three main pillars of Indonesia's educational development that have been established: (a) Increased and expanded access; (b) Improvement of quality, relevance and competitiveness; (c) Improved Good Governance, accountability and public image. Those three pillars are deemed important for Indonesia in order to deal with international and global movement on education (Subasman, 2015). Government should try its best to meet the demand of access, quality and accountability in its development especially in education sector. Those keywords should be at the center of the process of delivering the right of citizens especially in delivering basic right like education.

12 years compulsory education has been studied by Notoprayitno (2018). They found that the obligatory requirement of 9 years compulsory education is still being implemented in Indonesia. The program of the inclusive 12-years compulsory education policy demands appropriate new laws. Such laws should progressively administer the right to education for all, including children with special needs, and those children living in isolated locations, or under inauspicious social conditions. Research investigating the direction of education development policy referring to SDGs has been done by Singal (2019). It focused on the issues in the South Asian Context with the aim is to provide a critical overview of the whole region, the differing levels of research evidence among countries need to be acknowledged.

Indonesia has not shown good performance in terms of its Human Development Index. According to a report by the Human Development Report (HDR), United Nations Development Program (UNDP) in 2012, Indonesia's Human Development Index (HDI) ranking is 121 out of 187 in the world. This issue has been studied by several researchers (Arisman, 2018; Yuliani, 2016). This includes services the government provide in terms of education, health, and earnings per head ranking. To compare with, Indonesia's position is far below Singapore (18), Brunei Darussalam (30), Malaysia (64), Thailand (103), Philippines (114), and slightly better than Vietnam (127) and Myanmar (149).

Based on the three main pillars and reports (HDR), it is increasingly clear that human resource development has a very important role for the sustainability of a nation's development. Therefore, the development of quality and sustainable human resources in the Republic is absolutely necessary, for several reasons: to realize good governance and clean governance, and to become problem solver for Indonesian nation which is currently hit by multidimensional crisis.

Education is also seen as a vehicle to improve the quality of human resources. It is a crucial factor to develop any nation since it deals with human resources. It equips and prepare children and future generation to have proper knowledge, skills and competencies needed to participate in developing a country in many aspects. It has a variety of functions and side effects on human life in the community, nation, and state. If the country fails to develop education sector, there is a likely that a country will lose its future generation who will be able to deal with challenges and seize the opportunities to develop a nation and country. Therefore, the quality of education in a country is a benchmark of the progress of the nation. Apart from that, education is a human investment in the long term (Kagan et.al., 2019; Zhao, 2018). This is what a country need to take into consideration. Investing in human resources will benefit a country and a nation to reap competent and skillful future generation to participate in a nation and country development. 
On its journey, education as mandated by law and regulated in the above Government Regulation, is not an easy task to implement. In practice it is still faced with obstacles and problems both with regard to opportunities and expansion of access to education, effectiveness and efficiency, and accountability. These obstacles and problems must be taken seriously and the right solutions to be found in order to succeed national development in this country. In this regard, the opportunity and expansion of educational access are in accordance with the constitutional mandate as mentioned above, that every citizen is entitled to education. This is in line with the central government's Education for All (EFA) program, or in other jargon "no child left behind". In reality, it is difficult to achieve this goal. There are still those who have not got access to education (Ali et.al., 2018; Avalos \& Valenzuela, 2016; Hopkins, 2015). This may happen due to a number of reasons. Cultural and structural aspects can contribute to this failure. In addition, the remote and wide area geographically make it hard to accomplish the goals of delivering education to the citizen.

In Indonesian context, based on the Strategic Plan of West Java Education Office 20092013 there is still a large gap between the number of Primary School graduates who have not been accommodated in Junior High School. Likewise, graduates of Junior High School have not been accommodated in Senior High School or Vocational High School (Khairunnisa et.al., 2015). This resulted in the low level of continuing education for students. Based on national data, in 2010 children aged 16-18 numbered 13,169,628 of these, as many as 1.181.884 graduates of junior high school and the equivalent could not continue to secondary education level, and it will continue to grow every year. It is hoped that with the introduction of 12 -year compulsory education by the government, the opportunity to obtain secondary education can be evenly distributed throughout the country. Education will support regional development in West java (Riani, 2005). Like other aspects of development, education supports the human resource in terms of skill and competencies to deal with the development process in a particular province. Failure to meet this demand may hamper the process of the development in a particular province.

To improve quality national education, there are some ways to pursue. In connection with that, according to Surya (2007) the government continues to make efforts in improving national education. To create the quality of Human Resources (HR) in each region, the government also legalized the Regional Autonomy Law. It is expected that through regional autonomy, district/city government can have the opportunity to improve services and innovate education for its society. One form to improve education services is to expand access to education (Agustinus, 2016). In West Java, one city that has opened access to 12-year compulsory education for its citizens is city of Sukabumi. This program is a strategic bridge to improve the quality of Human Resources. 12 years compulsory education, both in the global order, national and local have bargaining power and also has a strategic role to boost human resources at national, regional and local levels. If the education program succeeds, it will support other aspects of development in local level. When local government is able to accomplish this educational goal, it may support the program at regional and national level in educational service for the citizen.

As a form of success in secondary education, Sukabumi won the first Vocational Award Cluster Award in 2011 and has been awarded Satya Lencana Pembangunan Pendidikan from the Governor of West Java associated with the 12 years compulsory education program of West Java Province, won two titles, Sukabumi considered successful in implementing the 12 years of intermediate education program at the provincial level of West Java. But in fact, the implementation of 12 years compulsory education in this city does not necessarily run smoothly because it still experiences obstacles both Internal and external constraints. Internal constraints: aspects of facilities and infrastructure, curriculum, educators, as well as financing 
aspects. While external constraints: family environment, community, business and industry. Those factors directly and indirectly can affect the implementation of 12 years compulsory education.

Implementation of 12 years compulsory education in Sukabumi City has served as an acceleration in delivering compulsory education for its citizen. Several reasons can be taken into consideration by the city government including: first, the decision of the minister of education and culture on the implementation of compulsory education; Secondly, the target of achievement of Participation Gross/Intermediate Participation Rate for children aged 7 to 12 years is complete while the age of 13 to 15 years for junior high school level has also been completed. Based on this circumstance, the city government implemented 12 years compulsory education. In addition, the government and society have shown their commitment in improving the quality of human resources. They have achieved in terms of physical and non-physical development.

Several researchers have conducted studies on the issue of education in national level (Megawanti, 2015; Suryana, 2017) at provincial level of West Java (Nahadi et.al., 2014; Slam, 2016) and more specific in Sukabumi regency/city (Handayani \& Tumija, 2016). However, research on 12 years compulsory education remains limited especially in local context. Therefore, this study was aimed at investigating strategic management undertaken by the Education and Culture Department of Sukabumi city government in the implementation of 12 years compulsory education.

\section{METHOD}

This research is qualitative and it applied case study featuring descriptive and comprehensive approach. Data were collected in the following steps: (1) determining qualitative data in the form of a detailed description of the situation, people, events, interactions and behavior, especially those related to strategic management; (2) using a holistic or thorough, inductive approach and moving from one fact to another until a general overview of the strategic management of the 12-year-secondary education was found; (3) applying a conceptual framework in order to limit the focus of attention in conducting research; (4) analyzing qualitative data inductively through comparative analysis in the form of narrative supported by causal network in order to find the prepositions which form the basis of the formulation of the basic theory or grounded theory; (5) analyzing and verifying research data from the beginning to the end of the research in a cyclical process.

Analysis and verification of research was examined through: (a) strategic management process of Secondary Education 12 years, (b) documents and (3) interviews. Data collected were reduced through the process of selecting, focusing, simplifying, sharpening, organizing and performing abstraction of data. After these reduction steps, a conclusion of the study can be reached and its truth can be tested. The location of this research was in Education and Cultural Office of Sukabumi. Triangulation with approach of snow ball by using purposive sample was applied. All such data were obtained directly on the situation in the field, or through the informant's opinions like: Head of Education and Cultural Office, Head of Secondary Education, School Supervisor, School Principal, School Committee, parents of students and other parties when needed. In addition, the data were also obtained through documentation studies, especially those relating to various notes on the implementation of the 12 years compulsory education program.

This study applies strategic management theory which consists of three processes, namely strategy formulation, strategy implementation and evaluation/control of strategy (Armstrong \& Taylor, 2014; Elbanna et.al., 2016; Favoreu et.al., 2016; Theriou, 2015). Strategic management focuses on integrating aspects of marketing, research and development, 
finance/accounting and production/operations of a business (Hitt et.al., 2016; Oyewunmi et.al., 2017). This study applies strategic management and it explores strategy formulation, trategy implementation and evaluation strategy for 12-year compulsory education in Sukabumi city.

\section{RESULTS AND DISCUSSION}

This study was aimed at investigating the implementation of 12 years compulsory education in Sukabumi city. With such condition, the stakeholders in this City plan and design educational breakthrough by facilitating their citizens to access education up to 12 years. To be specific it was aimed at investigating strategic management undertaken by the Education and Culture Department of Sukabumi City government in the implementation of 12 years compulsory education. The data will be organized into some section and followed by discussion in each result.

\section{Sukabumi City Government's 12 years Compulsory Education Program}

Based on the geographical facts, the position of Sukabumi City is located between two lanes, namely the capital city of Jakarta and Bandung, the West Java provincial capital. The position makes the city of Sukabumi very strategic to develop education, health and trade services. Sukabumi becomes a mega-urban city which may attract people who live in these two trajectories. Given the fact that Sukabumi city does not have the natural resources to boost its development, the city government developed efforts which are directed to human resource development. With such condition, the stakeholders in this city plan and design educational breakthrough by facilitating their citizens to access education up to 12 years.

This educational program can be seen in city government Regional Long-Term Development Plan for 2005-2025. The city embraces its vision which reads: Menjadikan Kota Sukabumi sebagai Pusat Layanan Bidang Pendidikan, Kesehatan, dan Perdagangan Berkualitas di Jawa Barat Berdasarkan Iman dan Kesalehan Kantor Pendidikan dan Kebudayaan Daerah (The Realization of Sukabumi City as Service Center Qualified Field of Education, Health and Trade in West Java Based on Faith and Piety Regional Office of Education and Culture). This vision determines the quality of education service to develop human resources who are pious, competitive, with high morals. Based on the vision of city government, education is designed as the core of development. This program may solve the limitation of Regional Official Revenue and Natural Resources in the present and future. The city program in education has been in line with the previous study on thi $\mathrm{s}$ issue. Education will support regional development in West java (Riani, 2005). As one of the regions in West java, the city should pay more attention on education to support regional development.

To realize the 12 years secondary education program, the city government needs to cater adequate facilities. The Office of Education and Culture of Sukabumi provides facilities for vocational school, junior high school in each region. This educational program is a new breakthrough in realizing the vision of the city and the vision of the Department of Education and Culture namely opening access to 12 -year education services for its citizens. In order to improve the distribution and extension of access to education, the city government implement strategies including the provision of education assistance funds for poor students in the form financial support the so-called kartu pintar/smart card.

There are some reasons why the City government implement 12 years compulsory education for its citizen: first, the age of 16-18 years is the productive age to gain knowledge and prepare for life in the future: secondly graduating student will get employment easier. Another reason is something to do with economic capacity of citizens in the city that require attention from government. Providing financial assistance for its citizens to get quality education services is the answer for poor family. It is important to remember that getting an 
education is the right of every citizen and it is the responsibility of the government to facilitate and finance it. This right is explicitly stated in the constitution 1945 paragraphs 4 and 3 of paragraphs 1 and 2. To fulfill the right of the citizen, the city should open and expand the access to education. One form to improve education services is to expand access to education (Agustinus, 2016).

Speaking of formal legal aspect, the process of 12 years compulsory education requires the legal support in forms of the policy. This legal support can be in both local level (Sukabumi City), regional level (West Java Province) and national level. When it comes to the implementation of the 12 years compulsory education program in Sukabumi City, the city has implemented this since 2005-2013 and from 2014 where The Ministry of Education Policy no 80 of 2013 on secondary education was signed by the Ministry of Education and Culture. In connection with this, the City Government has proven its vision to implement educational development in the form of access to 12 years compulsory education for every citizen.

In order to realize continuous and sustainable 12 years compulsory education, it is necessary to have systematic efforts and support from education stakeholders. To achieve this, Sukabumi City issued Local Regulation of City of Sukabumi Number 8 years 2008 about Medium-Term Development Plan of 2008-2013 and the launched of the acceleration of education acceleration 12 years on May 2, 2005 by the Mayor Drs. H. Muslikh Abdusyukur, M. Si. Although this might not be considered strong to be a legal basis, this is the basic capital for the implementation of 12 years compulsory education in Sukabumi city.

After the city government commenced the 12 years compulsory education in 2005, the city has achieved the targets for the program. The achievements included an increase in gross participation rate, pure participation rate, average school length, as well as increasing society skills, and the standard of living. These achievements are expected to increase Human Development Index (HDI) of Sukabumi City which includes education, health and purchasing power of the citizen. It is clear that education plays key role in terms of country development. The country should invest more to develop their human resource especially for their education. Apart from that, education is a human investment in the long term (Kagan et.al., 2019; Zhao, 2018).

\section{Program, Budget and Procedure of the Program}

The implementation of the 12 years compulsory education program in Sukabumi can be viewed from the aspect of the program, budget and procedure. The three aspects help the implementation of a particular program to succeed. A program requires budget and procedure. The Procedures ensure that the budget is spent in accordance with the regulation.

The data collection was conducted by the Education and Culture Office of Sukabumi City in 2005, 2012 and 2013. The data was used as reference for the allocation of 12 years compulsory education for students 16-18 years old who needed help. This refers to student who are in the level of senior high school. Students who come from low income families need to be supported to enroll and study in senior high school. This financial support will be a great help for students who could not afford to study in senior high school level (Khairunnisa et.al., 2015).

The budget was provided through strategic measures based on real needs. This was to ensure that the program was targeted and could be implemented effectively and efficiently. The data collection procedure required systemic and continuous coordination from lower level to upper level. It is also necessary for the involvement of related institutions, such as National Family Planning Coordinating Board, Statistics Bureau, NGOs concerned about education, School Committee and Education Board. Their participation and contribution play significant role to ensure that the implementation of educational program can be achieved by the city government. 


\section{The Evaluation of the Program}

The evaluation process for the 12 years compulsory education in Sukabumi City needs to be done. It can: serve as a benchmark of success; assess the effectiveness of the program; determine the suitability between the plan and the program, design follow-up plan for the next program; obtain information on program promoting and inhibiting factors; modify programs that were not in accordance with the existing facts. In management, the evaluation process is crucial to ensure that the goals are achievable. In addition, evaluation provides information and feedback to take into consideration in order to avoid failure in achieving organizational goals.

After program implementation, the Office of Education and Culture of Sukabumi City evaluated the process. This evaluation should be taken into consideration by the city government. It serves several functions for the city to ensure the implementation of the program. The evaluation results were submitted to several parties like the school, the Teachers Association of Indonesia, the Private School Board, and the educational community. Those parties are partner and collaborator with the city government to ensure that the education service is delivered and received by the society.

There were several feedbacks on the program implementation. First, the data collection process of drop out students and prone to drop out in 2012 by using Statistics Bureau's volunteers was considered unsuccessful. To overcome this, in 2012 the whole process was done by Section Head of Community Empowerment at the village and district levels. Second, the disbursement of school aid funds for underprivileged students, in 2005 and 2012 was done through card. In 2013 the channeling of funds was transferred through banks. Third, the accountability report for the use of Poor Student Assistance in 2011 was conducted per month. In 2012 and 2013 the report was done per quarter. Fourth, the data collection process of students drops out and prone to drop out was integrated.

\section{Environmental Analysis of the Program Implementation}

The Education and Culture office of Sukabumi City has made a strategic decision to boost the quality of its citizens. This was evidenced by requiring every citizen of Sukabumi City whose age was 16-18 years to enroll and study in senior high school. The decision was not an easy thing since it requires a mature and comprehensive analysis. Environmental analysis is the deciding factor in making a particular decision. This is in line with Wheelen \& Hunger (1993) who stated that the purpose of environmental analysis is to recognize the internal strengths and weaknesses of the organization and to understand the external opportunities and challenges of the organization, so that the organization can inspire future changes. In the context of Sukabumi City, the government can identify internal strength and weaknesses in the implementation of the program. Furthermore, the city has the chance to understand external opportunities and challenges in the implementation of the program.

Environmental analysis offers some uses and benefits. Senda as cited by Akdon (2006) stated that environmental analysis is useful for detecting important changes and events, especially with regard to social, political, economic and scientific and technological progress; identifying the challenges, opportunities or changes that such important events bring to the organization; provide information on future orientation to every level of leadership and staff; giving a signal to the whole range of what to do with the organization. The benefits of environmental analysis are to improve the quality of strategic decision making, and to improve organizational performance, clarify strategic vision and enhance understanding of changing environmental changes. In the context of program implementation, the city government can identify important changes and events in the implementation of the program. The city can improve its organizational performance to deliver educational service program for its citizens.

In analyzing the internal and external environments (ALI and ALE), the Office of Education and Culture did not include External Factors Analysis Summary (EFAS), Internal 
Factors Analysis Summary (IFAS), and Summary Factors Analysis Strategic (SFAS). The absence of these procedures leads to some missing information. There was no information on the most dominant factor and which factor had high, moderate, and low priority. Twelve years of middle education for residents of Sukabumi City is local policy taken by the Head of Region in this case the Office of Education and Culture as the executor in the field. This information can be crucial and contribute to the implementation program.

\section{Strategy For mulation of the Program}

After determining the strengths, weaknesses, opportunities and threats for program implementation, the next stage was a strategy formulation. This strategy includes the vision, mission, goals, strategies, policies and targets for program implementation. The office of Education and Culture Sukabumi City has determined the vision and mission in the future that is to realize a quality education and develop human resources who are devout, intelligent, competitive and performing noble character. Strategy formulation is crucial to ensure that the vision, mission, goals and strategies in implementing educational program in Sukabumi city can be formulated well.

The vision implies that the in the next five years, the people of Sukabumi City may achieve the quality of human beings who are intelligent in thinking, strong in character, and able to compete at local, regional and national level and even internationally. Through this vision, the city government realized that the efforts to realize a smart society will face problem if the degree of health and welfare level of society were not improved. It goes without saying that the three factors namely education, health and welfare are the three pillars to improve the human development index (HDI). Those three pillars are deemed important for Indonesia in order to deal with international and global movement on education (Subasman, 2015). In this context, the improvement of educational program contributes significantly for human development index.

The vision to develop intelligent people, healthy and prosper citizen would be meaningless if attitude and behavior of noble character were not taken into consideration to be the foundation. To realize this, the ideals of the religious community should characterize and develop the attitude and behavior of student. The vision is a far-reaching and widespread perspective. It is an abstract mind; has a powerful power and can break through all physical boundaries, time and place. Students' character has been the focus and central issue for the nation to place it in a national curriculum. Character should be taken into consideration in education.

In realizing this vision, the Education and Culture Office of Sukabumi City have some missions to increase the participation and expansion of access to education. This was evidenced by the realization of 12 years compulsory education that has started in the academic year 2005/2006 and to date (2014) still continues. This is in line with Robson (1997) on characteristics of mission. A good mission contains a clear, concise and encouraging impression; expressing strong values and beliefs about the future; focus on the conversation and make choices about the consequences. The city has set clear, concise and encouraging vision and mission in the implementation program of education.

After setting the mission, the next step is to set goals. The program has several objectives in an effort to deliver 12 years compulsory education. The objectives are: to provide educational opportunities for every child aged 16-18 years equally; to increase awareness and participation of the community (parents, community leaders and business and industry) in education; to help poor people to send their children to school at least 12 years of age; and to increase education quality in Sukabumi City. This is in line with David (1999) and (Wheelen \& Hunger, 1993) when it comes to goal setting. Goals (objectives) refer to specific outcomes of the organization to seek to achieve its basic mission. It has something to do with specific 
result that an organization seeks to achieve in pursuing its basic mission. Goals are the results to be achieved within the time limit; what result to accomplish; and when to accomplish.

To achieve 12 years compulsory education for children aged 16-18 years was not an easy task. It required adequate supporting facilities. To this end, the City Government in this case the Office of Education and Culture of Sukabumi City has provided educational facilities for vocational high school and senior high school per district. This was intended to facilitate citizens in accessing education, especially higher secondary education 12 years. Support from various parties both from parents, community and from business and industrial world were needed. One form of business and industry support in 12 years compulsory education was in the form of Memorandum of Understanding $(\mathrm{MoU})$ with vocational high school and provides scholarships for students who excelled in academic performance. Several researchers have conducted studies on the issue of education in national level (Megawanti, 2015; Suryana, 2017) at provincial level of West Java (Nahadi et.al., 2014; Slam, 2016) and more specific in Sukabumi regency/city (Handayani \& Tumija, 2016).

\section{Strategy Implementation of the Program}

Implementation is one of the most important factors in the management process. It focuses on program, budget and procedure. A successful strategic implementation is highly dependent on managers' skills (Theriou, 2015). The implementation of 12 years compulsory education covered several programs. The programs were geared to: increase opportunities to obtain education for children from poor families including those living in the suburbs; to assist children who were vulnerable to drop Out due to limited costs; and to provide the retrieval program to support 16-18-year-old school-age children who did not go to school/drop out for school with government support. To implement the program, adequate budget allocation was required. The allocation of funds for the students who were prone to drop out and have dropped out had been allocated funds in 2005 IDR 2,250'000/student per year and in 2012 IDR 4,670,000/student per year and for boarding students IDR 6,680,000/student per year. Not all students aged 16-18 years in Sukabumi City were from the poor family, some were struggle to afford education financially.

There was a procedure to assist students from poor families. The Office of Education and Culture of Sukabumi City performed a recruitment procedure involving all elements, both from government and non-government elements Indradjit \& Djokopranoto (2006). The procedure was rule or technique of system implementation to carry out a certain activity (Romiszowski, 2016). The procedure is often called as SOP (Standard operating procedure). The SOP contains details of the activities required to complete the organization's need. These recruitment procedures applied to students aged 16-18 years in 2005 involving 1,453 neighborhood units, 346 neighborhood units, 33 sub-districts and 7 sub-districts throughout Sukabumi. In 2012 the procedure of data collection involved all education stakeholders both internal and external. Internal recruitment was carried out by technical implementation unit at the district level and principal working group for senior high school/vocational and external recruitment levels conducted by whole level team.

To achieve the program implementation, the government's efforts were realized in several ways. Strong supports came in the form of provision financial assistance; the acceleration of rehabilitation of school buildings and the provision of educational credit for students from poor families the targets of that are the increasing average school length, increasing Gross Participation Rate and Pure Participation Rate in Sukabumi City. This effort has been done to ensure that financial aspect should not be a barrier for student to study in the school. This is in line with the central government's Education for All (EFA) program, or in other jargon "no child left behind". This effort is set to tackle the problem of students who had no access to education (Ali et.al., 2018; Avalos \& Valenzuela, 2016; Hopkins, 2015). 


\section{CONCLUSION}

This study investigated the implementation of 12 years compulsory education program which was conducted in Sukabumi city. Based on the results of this study, it can be concluded that the Education and Culture Office of Sukabumi City had no specific vision and mission for the implementation of 12 years compulsory education implementation. One of the missions which clearly brought result was the provision of financial support for the students that led to the decrease of drop out students. This mission was achieved through strategies included providing financial support in many programs like kartu pintar/smart card. This financial support played key role to ensure that students after graduating from junior high school could afford the higher level in senior high school.

The program implementations were based on programs, budgets and procedures. These three aspects were taken into consideration to analyze the program. In general, the implementation of the program fell into good category. This is to say that the program was delivered and it achieve several objectives. However, two programs had not been optimal in the implementation. This is to say that the city had difficulties to implement and achieve the program. Two barriers in implementation of programs are: retrieval programs and assisting program for students who were prone to drop out.

The city had experienced several problems during the implementation of the program. This happened because several reasons: first there were no clear sanctions for students/parents who did not attend 12 years compulsory education. Without sanction, parents didn't feel afraid to ignore the educational program. Second parents preferred their school-aged children to work to support family economy than to send them to school. This problem has something to do with economic factor. To support family economic ability, their parents choose their children to help them work and make money to support the income of family. Third, students were involved in drugs and promiscuity. This youth crime had an impact on the education program. Students who were in trouble with the law and were likely to be sent to jail were not likely to continue studying in the school. And fourth, funding support/financing from the government was still limited. This problem had something to with the city capabilities in allocating the budget for the educational program.

In terms of evaluation program, the city government had conducted this according to the system, type and management. This can be proven during the period of 2008-2012 the Gross Enrollment Rate (GER) and Pure Enrollment Rate of (PER) compulsory education in Sukabumi City which increased significantly. 2008 GER/PER: 110.2/97.04, year 2011 GER/PER: 111.42/97.38 and 2012 GER/PER: 113.80/98.93. the evaluation show that the city has to some extent achieved the objective of the program implementation for education. The implementation of the evaluation included 4 standards: Graduate Competency Standards, Content Standards, Process Standards, and Assessment Standards. In terms of accomplishment, those four standards had not received optimal attention from all stakeholders.

\section{BIBLIOGRAPHY}

Agustinus, H. (2016). The Effectiveness of Implementation School-Based Management in the Central Highlands of Papua Indonesia. International Journal of Education and Research, 4(10).

Akdon. (2006). Strategic Management for Educational Management Manajemen Strategik untuk Manajemen Pendidikan). Alfabeta.

Ali, Z., Siregar, S. H., Muhtar, S. N., \& Aridhayandi, M. R. (2018). Spiritual Leadership Values and Practices: An analysis in Islamic Higher Education. International Conference on Islamic Education (ICIE 2018). https://doi.org/10.2991/icie-18.2018.40 
Arisman. (2018). Determinant of Human Development Index in ASEAN Countries. Jurnal Ilmu Ekonomi, 7(1), 113 - 122.

Armstrong, M., \& Taylor, S. (2014). Armstrong's handbook of human resource management practice 13th Edition. Ashford Colour Press Ltd.

Avalos, B., \& Valenzuela, J. P. (2016). Education for All and Attrition/Retention of New Teachers: A Trajectory Study in Chile. International Journal of Educational Development, 49, 279 - 290. https://doi.org/10.1016/j.ijedudev.2016.03.012

David, F. R. (1999). Strategic Management. Prentice Hall International.

Elbanna, S., Andrews, R., \& Pollanen, R. (2016). Strategic Planning and Implementation Success in Public Service Organizations: Evidence from Canada. Public Management Review, 18(7), 1017-1042.

Favoreu, C., Carassus, D., \& Maurel, C. (2016). Strategic Management in the Public Sector: A rational, Political or Collaborative Approach? International Review of Administrative Sciences, 82(3), 435-453.

Handayani, N., \& Tumija, T. (2016). Strategi Pengendalian Kemiskinan di Kabupaten Sukabumi. Jurnal Ilmu Pemerintahan Widya Praja, 42(2), 37. https://doi.org/10.33701/jipwp.v42i2.149

Hitt, M. A., Xu, K., \& Carnes, C. M. (2016). Resource based theory in operations management research. Journal of Operations Management, 41, 77 - 94.

Hopkins, D. (2015). Improving the Quality of Education for All 2nd Edition. Routledge.

Indradjit, Y. S., \& Djokopranoto, R. (2006). Manajemen Perguruan Tinggi Modern. Andi Offset.

Kagan, S. L., Landsberg, E., Bull, R., \& Roth, J. (2019). Comprehensive Services, Funding, and Governance. In Sharon Lynn Kagan (Ed.) The Early Advantage: Building Systems That Work for Young Children, International Insights from Innovative Early Childhood Systems. Teachers College Press.

Khairunnisa, Hartoyo, S., \& Anggraeni, L. (2015). Determinan Angka Partisipasi Sekolah SMP di Jawa Barat. Jurnal Ekonomi dan Pembangunan Indonesia, 15(1), 91. https://doi.org/10.21002/jepi.v15i1.444

Megawanti, P. (2015). Meretas Permasalahan Pendidikan di Indonesia. 2(3), 227-234. http://dx.doi.org/10.30998/formatif.v2i3.105

Nahadi, N., Siswaningsih, W., \& Sarimaya, F. (2014). Profiles Junior High School West Java in Education Learning Environment. Journal of Education and Learning (EduLearn), 8(1), 65. https://doi.org/10.11591/edulearn.v8i1.206

Notoprayitno, et. al. (2018). Fulfillment of the Right to Education Through 12-year Compulsory in Inclusive Education. Advance Science Letters, 24(1), 296 - 299. https://doi.org/10.1166/asl.2018.11989

Oyewunmi, O. A., Osibanjo, O. A., \& Falola, H. O. (2017). Optimization by Integration: A Corporate Governance and Human Resource Management Dimension. International Review of Management and Marketing; Mersin, 7(1).

Riani, W. (2005). Pembangunan Pendidikan Sebagai Motor Penggerak IPM Jawa Barat. XXVI (3), $278-291$.

Robson, W. (1997). Strategic Management and Information System; An Integrated Approach. Prentice Hall.

Romiszowski, A. J. (2016). Designing Instructional Systems: Decision Making in Course Planning and Curriculum Design. Routledge.

Singal, N. (2019). Education of Children with Disabilities in the South Asian Context. In: Sarangapani P., Pappu R. (eds). Handbook of Education Systems in South Asia. Global Education Systems. Springer, Singapore. Global Education Systems. 
Slam, Z. (2016). Education Nonviolence through Child Friendly School. Tarbiya. Journal of Education in Muslim Society, 3(2), 186-204. https://doi.org/10.15408/tjems.v3i2.4983

Subasman, I. (2015). Program Evaluation Toward Millennium Development Goals in Education Aspect at Kuningan Regency West Java. Jisae: Journal of Indonesian Student Assesment and Evaluation, 1(1), 40. https://doi.org/10.21009/JISAE.011.04

Surya, M. (2007). Percikan Perjuangan Guru; Menuju Guru Profesional, Sejabtera, Terlindungi. Pustaka Bani Quraisy.

Suryana, S. (2017). Permasalahan Mutu Pendidikan dalam Perspepektif Pembangunan Pendidikan. Edukasi, 2(1), 12.

Theriou, N. G. (2015). Strategic Management Process and the Importance of Structured Formality, Financial and non-Financial Information. European Research Studies, XVIII (2), $3-28$.

Wheelen, Th. L., \& Hunger, J. D. (1993). Strategic Management and Business Policy: Entering 21st Century Global Society (Sixth Edition). Addiseion Wasley.

Yuliani. (2016). Pendidikan di Indonesia dalam Human Development Index (HDI). Journal Rontal Keilmuan PPKN, 2(2). http://dx.doi.org/10.29100/ppkn.v2i2.342

Zhao, Y. (2018). What works may hurt: Side effects in education. Teachers College Press. 